SECTION 12. Geology. Anthropology. Archaeology.

Hasanov EInur Latif oglu

$\mathrm{PhD}$ postgraduate, scholar of Ganja Branch of Azerbaijan National Academy of Sciences, Ganja, Azerbaijan

\title{
ETHNO-ARCHAEOLOGICAL AND ANTHROPOLOGICAL CHARACTERISTICS OF URBAN CULTURE OF GANJA
}

For the first time on the basis of innovative technologies have been researched the main typical characteristics of urban culture of Ganja. Also in this article were investigated some basic local national traditions of this ancient city.

Keywords: urban culture, Ganja, national traditions, innovative technologies, ethno-archaeological research.

Ganja city has an ancient historical past as the urban center. These typical features have a great role in research of urban culture of this city:

1. The majority of historical monuments, that are demonstrate the 4000 thousand year history of Ganja, which is the national wealth of our people, today gain unique place in the expositions of world's museums. Ganja, that has changed its location at least 4 times since its establishment, is located in a favorable position from the strategic point of view. That why it always has been the center of attention of foreigners. Ganja, that was the victim of a terrible earthquake many times, also was the subject of attacks of Mongols, Kharezms, Georgians, Arabs, Russians and other invaders. Ganja has turned to the arena of war damage of different countries of the world. But in spite of it didn't shaken, and using the genetic power revived and developed, and rose to the level of great cities. Protection of independence and state traditions by Ganja's people under Javad Khan's direction and showing an example of heroism against aggressive Tsarist Russia is forming a glorious page of our history [1].

2. "Turkish Revolution Committee of social-federalists", that showed the exceptional services in the establishment of the Azerbaijan Democratic Republic in 1905, Furkish edemiyyet", "Defense" committee and "Diphai" Party in Ganja, that was founded in order to protect our nation from the Armenian terrorism, once again showed, that Ganja people could bate all their creatures for traditions, statehood and independence.

Thanks to the representatives of the national bourgeoisie patriots, formed in Ganja, under the leadership of Nuri Pasha was created the Caucasus Islamic Army that saved Azerbaijan from the Armenian and Bolshevik forces ruthless 
genocide and created an incentive of the future of our country. For this reason, the capital of Azerbaijan Democratic Republic, that declared its independent in May, 28 in 1918, became Ganja. The leaderships of our first national state were outstanding and public men and statesmen, who have belonged to the noble family of Ganja.

On April 27, in 1920, after Azerbaijan Democratic Republic's overthrown by the Bolsheviks, that supported by bloody actions of XI Army, just only Ganja for the first time raised its statehood, independence and freedom voice against the Soviets. The arbitrariness of occupying army, shooting of innocent people, made Ganja people to begin Ganja rebellion against foreigners in a glorious page of history [2-5].

3. Today in native land of genius as Nizami Ganjavi (XII), Abu Hafs Genci (XI-XII), Abul Ula Ganjavi (XI-XII), Mahsati Ganjavi (XII), Sitte Ganjavi (XII), Qivami Mute rizi (XII), Raziyya Ganjavi (XII), Muhasib Ganjavi (XVIII), Sheikh Zaman (XVIII), Mirza Shafi Vazekh (XIX), Sheikh Ibrahim Gudsi (XIX), who gave great pearls to treasury of world science and culture, in the city Ganja carried out the non-oil sector, private enterprises, the development of new large industrial institutions, schools, medicine, and the establishment of cultural centers, on the basis of the specific programs construction and renovation works are being implemented successfully, the huge projects become a reality.

During the archeological excavations material - cultural remains have proved that Ganja, which is one of humanity's most ancient settlements, had played an important role in the history of the development of science and culture of our country. During passage point of Zoroastrian, moslim, and christian civilization, also location on the Silk Way from West to East, from North to South,suitable natural-geografical conditions, rich soil, mild climate, plentiful rivers, also talented and gifted people of Ganja played exceptional role for developing in Azerbaijan science and culture history.

4. Ganja is located on the ancient caravan routes, so merchants, travelers, scientists and cultural workers from different countries of the world visited Ganja, and first of all, their visiting helped our nation to integrate their spiritual values to all mankind civilizations.

Also in XI century, during the Arab Caliphate flowering, the great thinker Gatran Tabrizi's population in Ganja shows, that Ganja has become a major center of culture and science in the Muslim East. From the sources it becomes clear; in that period in Ganja there were personal and public libraries, medresses as modern universities, observatories and medical centers. Muslim culture has spread to the neighboring Christian states from here. That why, many scientists, poets, architects, artists from different countries of East settled in Ganja.

Also, Sheikh Nizami, appreciating Ganja's cultural level more highly, praised his native city "My Babil". In the middle of the XII century there were schools, medresses, private and public libraries, "The houses of wisdom" and 
"Health centers" in Ganja. In historical sources there was information that, in Ganja there was a large library "Dar al-kutub" that had been led by a famous scientist Abulfaz al-Nakhchivany. From Sheikh Nizami's reading and the names of the works, it becomes clear, that there were rich libraries in Ganja. Thus, about this regard the Sheikh of the Sheikhs says:

I said that I must create the work

And decorate it with tender ornaments.

All the book in world

I tried and found them.

I read and read

Works on arabian,bukhari,teberi and dari,

And I found pearls in every treasure,

From time to time from every paper

I tied samples

Then ,I tided my thoughts up

And wanted to write epos.

The high value of selcugs, that replacing Arabs, to the science and culture, was the reason of formation of a new school of poetry that was founded by Sheikh Nizami in Ganja.

5. In the scientific and cultural center of the East, in Ganja's literary environment were raised Abu Hafs, Abul Ganji, Abul Ula Ganjavi, Mehseti Ganjavi, Qivami Mutarrizi, Raziya Ganjavi, Mirza Shafi Vazeh, who gave priceless pearls to the treasures of world culture. As always, in the XVI-XVII centuries, Ganja gave to humanity persons, that had improved science and culture of Azerbaijan. Musahibi Ganjavi's and Sheikh Ibrahim Qudsi's names can be mentioned. We should not forget that Sheikh Ibrahim Qudsi, that was from the great Azerbaijani poet Nizami's family, as a well-known historian wrote a book Farixi muqeddes".

Throughout the centuries, the students in madrasas and in religious schools learnt the classical Eastern literature and world sciences. Ganja in the first half of the XIX century Ganja also played an important role in the development of science.One of the founders Eastern philosophy in Russia was M.D.Topchubashov (1784-1869), who lived and worked in Ganja, and also got his education here. In 1877 in part of the Iranian embassy he went to St. Petersburg, and later as professor of St. Petersburg University was one of the founders of the department of ancient Russian Archeological Society and headed East department until the end of life. Among the thinkers, that lived and created in Ganja, we can name Mirza Mehdi Naji, Mullah Abdullah, Haji Abbas, Khaki and others. According to the sources, at the end of XIX - at the beginning of the XX century in Ganja have worked already libraries, mainly consisted of the textbooks. The first publishing house in Azerbaijan owned by brothers Hamidov also was created in Ganja. 
Should not forget that, great patriot intellectual Nasib bey Yusifbeyli, who grow up in Ganja, was one of the founders Azerbaijan Democratic Republic that was the greatest historical achievement of our nation. On September 01, 1919 at the meeting under his initiative parliament decided to establish the Baku State University [5-8].

After a few days of the overthrow of the monarchy Hasan bey Agayev, Rustambeyli Shafi Bey, Khalil Xasmammedli, brothers Sheyxzamanli under the leadership of Nasib bey Yusifbeyli in history of Azerbaijan for the first time founded a new party- Furkish Ademi merkeziyyet firgesi" that, supported Europe's cultural values .

Hasan bey Agayev closely engaged in publicism, and in 1911 he published the newspaper "Yujniy Kavkaz" ("South Caucasus"). This great intellectual was elected the chairman of the society that spread education among the Muslims. His greatest service to medical science of Azerbaijan was his foundation together with Khudadat bey Rafibeyli the medical society in Ganja. The first "Medical Society" in that, was established by Hasan bey Agayev and Khudadat bey Rafibeyli, stimulated the development of medical science. Since the foundation of Azerbaijan State Agrarian University till today, lots of ten thousands of highly qualified specialists in agriculture have been trained.

There are prominent scientists, statesmen and public figures, parliamentary deputies, heads of local and central executive power bodies among the graduates of this Academy. The Academy has educational and scientific relations with higher agricultural schools of USA, France, Germany, Iceland, Turkey, Iran, Holland, Spain and CIS countries.

In addition, in Ganja Regional Scientific Center, which serves for new poetic translations of the works of the great Azerbaijani poet Sheikh Nizami, for investigation of the poet's literary heritage and widens the mind researches,"Nizami Ganjavi Center" has been working.

With the aim of delivering investigation works in the western part to the scientific community, in Azerbaijan National Academy of Sciences on exact and public sections the scientific journal Xeberler" (-News") and magazine "Nizami study" are published.

In 1938 Ganja Teachers Institute started its activity during two year and after 5-year activity it became Ganja State Pedagogical Institute named H. Zardabi and could give higher education.

Institute of Technology of Azerbijan has been created at the initiative of the Azerbaijani National Leader Heydar Aliyev, according to decisions No. 202 of the USSR Council of Ministers, dated February 22, 1979, and No. 206 of Azerbaijan SSR Council of Ministers, dated July 10, 1980, firstly in the South Caucasus, in the basis of branch of Kirovabad (now Ganja) Polytechnic Institute of Azerbaijan, named Chingiz Ildirim and combined Baku branch of Krasnodar Polytechnic Institute, also the specialty of "wine technology" of Azerbaijan Institute of Agriculture, named S.Agamalioglu. On the basis of Ganja Regional 
Teacher Training Institute and Ganja's College of household under Decree No. 349 of National Leader Heydar Aliyev, dated June 13, 2000, was established the branch of Azerbaijan Institute of Teachers in Ganja. During the Soviet times Ganja brought up such great scientists, a s Mehdi Juvarly, Chingiz Juvarly, Maksud Aliyev, Mammadali Aliyev, Ali Guliyev, Aladdin Guliyev, Hamid Arasli, Rustam Aliyev, Akbar Babayev, Gazanfar Aliyev, Qasim Qamberoglu, Qahraman Qaragashli, Mirali Gashgai, Isaac Jafarzadeh; the rector of Baku State Pedagogical University and Baku State University, worked for a long time, Mehdi Aliyev, former rector of the Azerbaijan Oil Academy, a prominent scientist in the chemical Tofik Aliyev, Nuraddin Kazimov, Asaf Hajiyev and others, who has gained great success in various spheres of science and education and played role in development of science of Azerbaijan.

The first vaccine preparing plant in Republic and wine-making plant, The Scientific Research Institutes of Plant Protection, of silkworm breeding, of cotton-growing, of cattle-breeding science and Agro-mechanics are working nowadays

Thus, the above-mentioned facts once again demonstrate that, as in all stages of history, today Ganja also has its specific role in the development of Azerbaijani science.

There are state schools providing general education, and also non-state schools providing general education in Ganja. There are 49 state secondary schools providing general education with highly qualified teaching staff in the city, 1 special school for children with limited health, three boarding schools, 3 vocational schools, technical and the humanitarian colleges, music technical school, medical school, technical school, school of farmers and entrepreneurs, 3 vocational high schools, Turkish private school, "Araz" preparation courses for universities, foreign language and computer centers, the house of education employees are working in Ganja .

School № 4 of the city, named Mehdi Mehdizade, with an English bias ,became a member of the Association of UNESCO schools. Today, more than 1,300 professionals are working in the education sphere of Ganja.

Library: The history of creation of Ganja's libraries is belong to the beginning of the last millennium. Also there were great libraries in Ganja in the $\mathrm{X}$-XI centuries. The famous Arab traveler and geographical scholar Yagut Hamavi in her work "Macatal-bulan " shows, that there was a great library "Dar -al- kitab" under the leadership of the scientist Haddad ibn Bekran Abulfazalan Neshevi, that had widen the scientific environment of Ganja. At the end of the XVIII century there was a popular library "Sultaniyye", that was the cradle of science and culture of Ganja. At that time, there was a large library of Javad khan in Ganja. Unlike others this library had been using free by the urban population.

In connection with the 100th anniversary of the famous Russian poet A.S.Pushkin, there was established Nizami - Pushkin Library in Ganja. In 1934 
Ganja city Education Department organized the City Central Library. Since 1976, all libraries in the city centralized around the Central Library and created Centralized Library System (CLS).

Thus, the above-mentioned facts, once again demonstrates Ganja's specific weight, as in all stages of history, in the development of Azerbaijani science today.

More than 60 different medical institutions serve for the health of townsmen of Ganja. Currently, 20 hospitals, the Central Clinical Hospital, Eye diseases hospital, infectious diseases, Endocrinology, Psychiatry, 2 Children's Hospital, First Medical Aid, Railway hospitals, 13 Ambulatory polyclinics, 5 Dispenser, 3 Medical Sanitary Section; 9 Medical Center: Diagnosis, Ganja pensioners Territory Social Service, Ganja Railway Hygiene and Epidemiology, Reproductive Health and Family Planning, Escallop Medical Center, Orthopedic Prosthetic Center, Beauty and Health Center, 2 Consulting also the First Aid Station, Children's tuberculosis sanatorium and Maternity hospital are working here. In whole, there are 1387 doctors and 2622 nurseries work in medical centers of the city.

The modern medical facilities, located in the city, are equipped with highquality medical equipments. After the capital Baku, Ganja is the second largest center of science and culture of Azerbaijan. Because of region, where located the city in the South Caucasus has very important strategic position, in the I-IV millennium the main caravan route that connected trade centers of the Middle East and Front Asia, were here. The ancient city Ganja found development on this trade way and over thousands of years were one of the well-known cultural centers.

Today, according to the history tradition, after the capital of Azerbaijan Baku, Ganja is the second largest center of science and culture. Theater, music, museums and libraries, that reflecting the cultural level of the city, contributes development of the intellectual sphere.

Theater: The history of art and theatre is ancient in Ganja and its foundation begins with the initial period of human society. Even from the Middle Ages in Ganja in ceremonial and religious holidays there were shown square performances were performed different scenes.

Performances, that shown by amateur troops and played scenes, accompanied by music, gave good mood to the population and made thinking them.

Even at the end of the XIX century by amateur theater groups in Ganja have been staged plays of M.F. Akhundov, N. Narimanov, N.B. Vezirov and other well-known writers . In 1906, by amateur drama group has been created the 38seat " Ganja Muslim drama party" .

Well-known thinker, a patriot Ganja intelligent, an active member of the Party "Difai" and the society Mirza Muhammad Akhundov was founder of 
theater culture and wrote work "What is the Teatro?" about theater's role in society .

The first great national theater in Ganja was in 1933, on the basis of Fengid-teblig theater" ("critical-promoting theater") in Baku, that was founded in 1933.

In 1954to Ganja's theater was given the name of well-known playwright Jafar Jabbarli. Ganja theater traditions are connected to such famous persons as M.Sheyxzamanov, M.Hemzeyev, B.Shekinskaya, I.Afandiyev, M.Davudov. In this magnificent temple of art, were performed successfully several times not only Azerbaijani, but also Russian, European and world classics works. Alakbar Seyfi, Ismail Talybly, M. Burceliyev, Sedaye Mustafayeva, Ashraf Yusifzade, Aladdin Abbasov and other talented actors have created characters that opened in Ganja theater's history unforgettable pages

Music: An ancient cultural center of Azerbaijan Ganja is rightly proud of well-known persons and valuable contribution that it has given to treasury of the world's musical culture.

An ancient Ganja and Ganjabasar is the land of Ozan's, the cradle and hot spring Ashuq's art. It becomes clear from the information in the book «Kitabi Dede Korkut» (VII century), that ozan's history in our territory is very ancient. Ozans, who had taken "Qolcha Gobuz" (an old Azerbaijani musical instrument) and shared from country to country, from man to man people's happiness and sadness, were the leaders of people's parties. The most ancient stringed musical instrument gobuz is a predecessor of the modern ashuq's saz. Dede Korkud's expression "gobuz is sacred" shows respect of our nation to music.

In the Middle Ages in Ganja poets, musicians, wise men and artists had meetings and were talking about science, literature, music, art. An existence of such kind of meetings prove participation of the first well-known poetess of Azerbaijan, the first woman chess player and the first prominent female musician Mahsati Ganjavi (XII century)and other scientific and literary sources.

Creation heritage of the great poet and thinker of Azerbaijan Nizami Ganjavi (1141-1209) on the universal importance gave rich information to the national culture, and also influenced to the development of literature and art. Nizami's characters have become the symbols of the culture of Azerbaijan. Many composers created vocal works, operas and ballets, symphony and other eternal music, that praised Nizami's poetry in music, and enriched world's culture.

Renaissance poet Sheikh Nizami's "The Treasure of Secrets", "Khosrov and Shirin", "Leili and Majnun", "Seven Beauties", "Iskendername" poems hunting and military music, vocal and instrumental music, palace, and folk music, lyric music, dance music, musical instruments and music performers, theory aesthetic problems of music, based on the oral tradition of professional music, mugham, classified forms, educational importance and others are 
explained in poetry form, and given valuable information about 8 mughams and 40 national musical instruments .The works of Nizami Ganjavi reflect musical culture of the East, the whole country, and also rich musical life of the poet's own city - of Ganja .

Music, singing always has a great place in the life of Azeri people. Even in the early periods of human history all the household and religious ceremonies are accompanied by music. We know that, in VII centuries, Dede Gorgud played on gopuz.

In IX-XII centuries the music genre developed in Ganja. In palaces stringed, wind, percussion musical instruments are widely used in the mughams, singers sang songs, and artists have won fame with beautiful music works in the Middle East.

Along with mugham in Ganja ashug art widely spread among the people.

In XI-XII centuries there were creative meetings in Ganja, where singer, musician and poets took part. In such meetings the representatives of literature and art of that period, including Mahsati Ganjavi, also took part. Great Nizami Ganjavi in his works has said the name of thirty popular musical instruments that were widely spread in Azerbaijan at that time. This fact also proves that in XII century and more that earlier Azerbaijan people had high musical culture.

Ganja city, that has high music feeling and the music culture, gave to the history of Azerbaijan national music such well-known composers as Meshedi Jamil Amirov, Fikret Amirov, Ganbar Huseynli, Zerif Gayibov, Telman Aliyev and Alakbar Tagiyev.

The love tradition to music lives in Ganja till nowadays. At present, State Philharmonic Society, "Goy-gol" State Song and Dance Ensemble, Orchestra of Folk Instruments, Ganja State Chamber Orchestra, music techniques, music schools are functioning in Ganja All genres of music - ashug, folk songs, opera, also the types of modern music have developed a high levelly in Ganja.

Museums: The Museum of Ethnography of History, named after Nizami Ganjavi that consists of two departments was founded in 1924. In the museum organizing there was the role of a group of teachers and students of the Seminary of Ganja. If in the first years of its inception, there were 500 exhibits in museum, the total number of museum's exhibits in nowadays more than 30 thousand. At present time, the main fund of museum 24785 exhibits is reserved. 4438 of them are archaeological exhibits, 1648 ethnography, 392 painting, 9 sculptures, 2753 picture, 9259 document, 3441 numismatics, 1984 books, 816 are in the areas of patriotism. Today, ancient, medieval, and numerous exhibits of modern period are shown in 18 rooms with total area of $972 \mathrm{~m} 2$ for the people who like history. Museum's exposition shows historical development of ganja from ancient times till nowadays.

6. In addition in Ganja also actives the museum, that devoted to Azerbaijani

National Leader Heydar Aliyev, Nizami Memorial House Museum, Mir 
Jalal Pashayev Memorial Museum, the first Soviet Union hero - Israfil Mammadov's Memorial House Museum, Museum of Independence of Azerbaijan Democratic Republic, also the museum -Cucelerim" Children's Creative center which has no analogue in the world and a number of smallsized museums are operating in Ganja. In Ganja, which has ancient and rich culture and traditions of the table, still has preserved Azerbaijani national cuisine traditions. Ganja kitchen with its national characteristics is differs from other regions of Azerbaijan. The cooked dishes, prepared sweets, sherbet (sweet drink) are differing for their tasty and manufacturing technology. Ganja has a positive impact on national food composition in the human body, is the health service. Ganja harmoniously combines kitchen culture, its history, philosophy, table psychology, traditions, physiology, hygiene, chemistry, equipment, ethics, esthetics, poetry and other aspects of the culture of the table.

7. Most unique culinary samples of Ganja, including plov, kebab, changal, chigirtma, pity, dovga, cream, cheese, oven bread, thin, lavash, pakhlava, zilviyye, sherbet, rose water, lemon tea, different kinds of jam, acids and other meals are extremely delicious. Most of the meals, including to Ganja cuisine are Turkish origin. For example,"dolma" comes from the word -doldurmaq" (in translation it means fill", basdirma" from basdirmaq" (means landfill cover), -chigirtma" from -chigirtmaq" (make cry),"bozartma" comes from bozartmaq" (to boil).

Measured at the thousand ages, ancient Ganja's national kitchen culture as a result of old experience of our progenitors, from generation to generation came to the present day.

8. After spreading Islam religion in Azerbaijan, Ganja got a status of the provincial center of the Arab Caliphate, and in whole Islamic world found fame as a center of science, education and culture. One of the important pilgrimages in the world of the VII-VIII centuries, the complex Imamzade, which named «Blue Imam», and where one of the sons of Imam Mohammed Bagir Prince Ibrahim was buried in, made Ganja city famous as the city of Imam Hussein of the Islamic world. At present, $98.96 \%$ of the populations of Ganja are Muslims. There are tens of Muslim mosques, the Russian-Orthodox Church, number of Albanian and German churches in Ganja. Ganja's people like Islam's science, philosophical bases and equally, they demonstrate a good attitude and religious tolerance to all religions [2-6; 8-11]. This argument is an indication of religious tolerance of Ganja's population and all of these facts prove the historical past of urban culture of Ganja.

\section{Bibliography:}


1. Mustafayev C. Orta əsrlərdə sənətkar təşkilatları // Cahan jurnalı, 1998, №4, s.17-21

2. Алиева А.С. Ворсовые ковры Азербайджана XIX - нач. XX веков. Баку: Элм, 1973, с. 21-25

3. Ohmədov F.M. Gəncə şəhərinin yerdəyişmələri / Gəncə tarixinin aktual problemləri. II elmi-praktik konfransın materialları. Gəncə: Elm, 2010, s. 53-63

4. Häsänov E.L. Die Gändschänischen teppiche von XIX - XX Jahrhundert als geschichtliche - ethnographische quelle / European Science and Technology (Die Europäische Wissenschaft und die Technologien): $2^{\text {nd }}$ International scientific conference. Bildungszentrum Rdk e. V. Wiesbaden, (Germany) 2012, p. 26-27

5. Guliyeva N.M., Hasanov E.L. Investigation of basic decorative-applied arts of Ganja on the basis of some innovative arguments and technologies / Science and Society: Proceedings of the 3rd International scientificpractical conference. London: SCIEURO, London, (Great Britain), 2013, p. 281-291

6. Həsənov E.L. Gəncə İmamzadə türbəsi (tarixi - etnoqrafik tədqiqat). Bak1: Elm və təhsil, 2012, $268 \mathrm{~s}$.

7. Филштинский М. История арабов и халифата (750-1517). Москва, 2006

8. Həsənov E.L. Məhsəti Gəncəvi dövründə sənətkarlıq / Craftsmanship during the period of Mahsati Ganjavi. Gəncə: Elm, 2013, 175 s.

9. Hasanov E.L. Some innovation historic-ethnographical arguments about development of craftsmanship in Ganja / Science, Technology and Higher education: Proceedings of the 1st International scientific practical conference. Westwood: Publishing office Accent Graphics communications, Westwood, (Canada), 2012, p. 485-491

10.Hasanov E.L. Innovative approach to teaching and research of some traditional craft branches of Ganja of the end of XIX century // International journal of experimental education (Problems of international integration of national education standards: Proceedings of International scientific conference - France, Paris), 2013, № 2, p. 81-83

11.The dawn of Art. Leningrad: Aurora Art Publishers, 1974, 196 p. 